\title{
Prevalence and comorbidity of relapsing polychondritis
}

\author{
Jonas F Ludvigsson ${ }^{1-4}$ \\ Ronald van Vollenhoven ${ }^{5}$ \\ 'Department of Medical Epidemiology \\ and Biostatistics, Karolinska \\ Institutet, Stockholm, ${ }^{2}$ Department \\ of Pediatrics, Örebro University \\ Hospital, Örebro, Sweden; ${ }^{3}$ Division \\ of Epidemiology and Public Health, \\ School of Medicine, University \\ of Nottingham, Nottingham, UK; \\ ${ }^{4}$ Department of Medicine, Celiac \\ Disease Center, Columbia University \\ College of Physicians and Surgeons, \\ New York, NY, USA; ${ }^{5}$ Department \\ of Rheumatology, Amsterdam \\ Rheumatology \& Immunology Center, \\ Amsterdam, the Netherlands
}

\author{
This article was published in the following Dove Press journal: \\ Clinical Epidemiology \\ 30 September 2016 \\ Number of times this article has been viewed
}

Relapsing polychondritis (RP) is by no means an unknown disease, and already 30 years ago Michet et $\mathrm{al}^{1}$ had presented results from a single-center study of 112 patients with RP. In contrast to the earlier study, ${ }^{1}$ the study by Horvath et $\mathrm{al}^{2}$ published in Clinical Epidemiology allows some interesting revelations.

Horvath et al used the nationwide social security number assigned to all residents in Hungary to link the Hungarian Health Care Database and the Hungarian Drug Consumption Database. Having access to data on the total population, Horvath et al were, as opposed to Michet et al, ${ }^{1}$ able to calculate the incidence of RP. Based on 256 patients with RP during 124 million person-years of follow-up, the incidence of RP in Hungary was $\sim 2 /$ million person-years, slightly less than that of a recent US population-based study. ${ }^{3}$

The Hungarian study has a number of strengths. Where earlier studies from tertiary centers may have reflected RP patients with a more severe disease than the average patient, the study by Horvath et al is population-based. This may explain why the researchers found higher survival rates in RP than earlier studies. ${ }^{1}$ The 10-year survival rate in Hungarian RP patients was $\sim 80 \%$ and this is similar to the age-specific mortality in the general Hungarian population. RP is most commonly seen in individuals aged $40-60$ years.

Another strength is their access to drug consumption data that allowed them to divide patients into groups of assumed severity. Here, however, it should be admitted that the researchers never actually saw patients (it was a strictly registry-based study), and in an ideal setting, each patient's disease activity should have been measured by a physician. Horvath et al used a predefined algorithm to grade patients into confirmed and suspected cases. For certain analyses, it is reasonable to restrict data to patients with a high likelihood of disease. Overall, an RP diagnosis in the Hungarian Health Care Database had a positive predictive value of $90 \%$, very similar to the accuracy of similar databases in other countries (for instance, the positive predictive value in the Swedish Patient Registry is $85 \%-95 \%)^{4}$

Although their network analysis of associated diseases in RP is slightly difficult to grasp, it is clear that some diseases stand out as linked to RP. The high lifetime prevalence of autoimmune disease was expected given the association with DR4 (also seen in, eg, type 1 diabetes $^{5}$ and even more so in patients with overlapping type 1 diabetes and celiac disease ${ }^{6}$ ). Although it is likely that RP is linked to other immune-mediated disorders, considering the mentioned DR-4 association, the authors may have over
Correspondence: Jonas F Ludvigsson Department of Medical Epidemiology and Biostatistics, Karolinska Institutet, Stockholm-17177, Sweden

Tel +46196021000

$\mathrm{Fax}+4619187915$

Email jonasludvigsson@yahoo.com 
interpreted some of their other comorbidity findings. It is difficult to make firm conclusions on the risk of cancer, osteoporosis, and even more so on the risk of rare outcomes such as adverse pregnancy outcome and congenital malformations in 256 patients, especially without a large reference group. Cancer is, for instance, a common cause of death in all older people and its occurrence in a quarter of the RP population may not constitute a true risk increase. Osteoporosis may be secondary to the corticosteroids that are commonly used to treat RP, and more data are needed before general osteodensitometry is introduced among RP patients.

The authors also urge caution when speculating about risk factors such as ultraviolet sunshine and exposure to toxic agents in drinking water based on geographical differences within Hungary. More data are needed, but the study of Horvath et $\mathrm{al}^{2}$ makes an excellent start in this exciting field.

\section{Disclosure}

The authors are researchers and this editorial represents their own personal views and not necessarily those of their employers. The authors report no other conflicts of interest in this work.

\section{References}

1. Michet CJ Jr, McKenna CH, Luthra HS, O'Fallon WM. Relapsing polychondritis. Survival and predictive role of early disease manifestations. Ann Intern Med. 1986;104(1):74-78.

2. Horvath A, Pall N, Molnar K, et al. A nationwide study of the epidemiology of relapsing polychondritis. Clin Epidemiol. 2016;8:211-230.

3. Kent PD, Michet CJ Jr, Luthra HS. Relapsing polychondritis. Curr Opin Rheumatol. 2004;16(1):56-61.

4. Ludvigsson JF, Otterblad-Olausson P, Pettersson BU, Ekbom A. The Swedish personal identity number: possibilities and pitfalls in healthcare and medical research. Eur J Epidemiol. 2009;24(11):659-667.

5. Pociot F, Lernmark A. Genetic risk factors for type 1 diabetes. Lancet. 2016;387(10035):2331-2339.

6. Smigoc Schweiger D, MendezA, Kunilo Jamnik S, et al. High-risk genotypes HLA-DR3-DQ2/DR3-DQ2 and DR3-DQ2/DR4-DQ8 in co-occurrence of type 1 diabetes and celiac disease. Autoimmunity. 2016;49(4):240-247.

Dove Medical Press encourages responsible, free and frank academic debate. The content of the Clinical Epidemiology 'Editorial' section does not necessarily represent the views of Dove Medical Press, its officers, agents, employees, related entities or the Clinical Epidemiology editors. While all reasonable steps have been taken to confirm the content of each Editorial, Dove Medical Press accepts no liability in respect of the content of any Editorial, nor is it responsible for the content and accuracy of any Editorial.

Clinical Epidemiology

\section{Publish your work in this journal}

Clinical Epidemiology is an international, peer-reviewed, open access, online journal focusing on disease and drug epidemiology, identification of risk factors and screening procedures to develop optimal preventative initiatives and programs. Specific topics include: diagnosis, prognosis, treatment, screening, prevention, risk factor modification,

Submit your manuscript here: https://www.dovepress.com/clinical-epidemiology-journal

\section{Dovepress}

systematic reviews, risk and safety of medical interventions, epidemiology and biostatistical methods, and evaluation of guidelines, translational medicine, health policies and economic evaluations. The manuscript management system is completely online and includes a very quick and fair peer-review system, which is all easy to use. 